DOI: https://doi.org/10.31933/dijdbm.v2i1

Received: $15^{\text {th }}$ October 2020, Revised: $15^{\text {th }}$ November 2020, Publish: $10^{\text {th }}$ December 2020

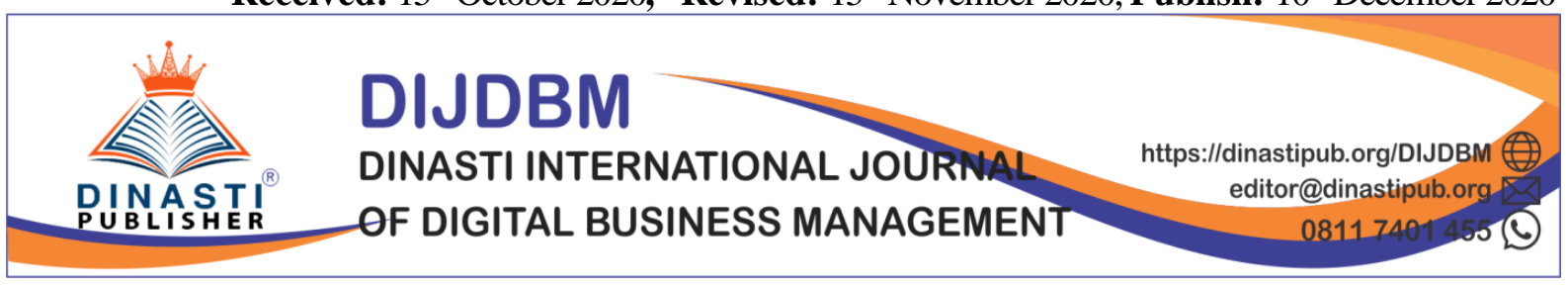

\title{
DEVELOPMENT MODEL OF SOCIAL MEDIA MARKETING - CONSUMER LOYALTY MEDIATED BY BRAND EQUITY AND CONSUMER RESPONSE TO FASHION BRANDED PRODUCTS
}

\author{
Ade Octavia $^{1)}$, Husni Hasbullah ${ }^{2)}$, Yayuk Sriayudha ${ }^{3)}$ \\ ${ }^{1)}$ Fakultas Ekonomi dan Bisnis, Universitas Jambi, Indonesia, octaviafebunja@gmail.com \\ ${ }^{2)}$ Fakultas Ekonomi dan Bisnis, Universitas Jambi, Indonesia \\ ${ }^{3)}$ Fakultas Ekonomi dan Bisnis, Universitas Jambi, Indonesia, yayuksriayudha@ gmail.com
}

\section{Corresponding Author: Ade Octavia}

\begin{abstract}
Cunsumer loyalty is determined by a positive response to the perceived experience. The use of social media in marketing products can improve the quality of marketing. The purposes of this research are to: (1). Explain the relationship between social media marketing and consumer loyalty with brand equity as a mediation variable. (2). Explain the relationship between social media marketing and consumer loyalty with consumer response as a mediation variable (3). Develop a model of social media marketing and consumer loyalty relationships. The design of the research was done quantitatively to analyze the model of the relationship between social media marketing and consumer loyalty. To interpret quantitative results used focus Group discusion (FGD) methods and literature studies. The research sample numbered 200 respondents with consumer criteria of users of branded fashion products. Analysis tools using SEM with PLS Software. The results showed a positive and significant relationship between social media marketing to the consumer loyalty of fashion products both before and after mediated by brand equity and consumer response. The priority of the research to be conducted lies in how digital development in marketing contributes thought to the business world, government and how this study strengthens the theory for similar research.
\end{abstract}

Keywords: brand equity, consumer loyalty, consumer response, social media marketing

\section{INTRODUCTION}

Consumer loyalty is still an interesting issue in marketing research. Some variable consumer loyalty tests have been empirical tested and resulted in loyalty models that can be applied in the business world. Consumer loyalty is not formed in a short time but through the learning process from experience (Octavia and Sriayudha, 2020). If the consumer is already loyal to a brand and has high engagement, then the negative news about the brand will not change the level of consumer involvement in consuming a product (Lee and Jung, 2018). Furthermore, consumer interaction with brand equity affects consumer loyalty (Gen Li et al, 2019). This is in line with Yang and Lee's opinion (2019) which found that brand personality, brand commitment and quality perception are variables that affect consumer loyalty. Even for the 
consumer segment of Muslims, beliefs, religions and relationship marketing have a positive effect on consumer loyalty to brands (Abdulrazak and Gbadamosi, 2017).

Social media gives marketers the opportunity to change how products are created, distributed, consumed and shipped (Godey et al, 2016). The existence of social media as a marketing communication medium is very profitable for marketers so as to increase the popularity of brands and companies (Octavia et al, 2020; Chu et al , 2019; Moriansyah, 2015: Oberain, 2017). According to Pew Research (2018), Facebook and You Tube dominated social media by 73 percent and 68 percent. At the same time, for 18 -year-olds users dominating the use of various platforms. Approximately, 78 percent of social media users use Snapchat, 71 percent of this group use Instagram, and nearly half are Twitter users. This figure is almost similar to the phenomenon in Indonesia. According to the Digital Around the World (2019) report, approximately 150 million Indonesians use social media platform or about 56 percent of Indonesia's population. The average 18- to 34-year-old spends 3 hours and 26 minutes using social media for work or other purposes. For the company, this is a huge market opportunity especially to strengthen brand equity.

When connected in a common interest then consumers have unconsciously formed a community. Han et al (2019) found that attachment in an online community has a positive impact on the loyalty of that community. In the concept of competition more and more manufacturers exist in the same industry, then the level of competition is higher especially in terms of seizing market share and customer mind share. Trust is the key to success in getting loyal consumers. The interesting question is whether brand equity and consumer response can be the mediation of marketing relationships through social media with consumer loyalty?. In reality the phenomenon of gap use of social media as communication and distribution of products is able to shape consumer loyalty.

There are different responses against the various loyalty programs offered by brands or companies to bind the hearts of consumers. Lee et al's research (2019) observed that consumers who pay a member fee have a higher response rate to loyalty programs than those who are not paid. Especially if the loyalty reward is earned by consumers for a short time, then the level of loyalty to a brand will be high. This indicates that the level of consumer response will determine the preference of consumers towards a particular brand and if simulated at the price will affect consumer loyalty (Yadav and Rahman, 2018). There is an interesting research from Yang and Lee (2019) which is showed how teenagers in Korea and China respond differently to European brand products and Asian brands. It turns out that brand personality through perception of quality affects consumer loyalty at different levels, in this case it is a fashion product.

Consumers buy luxury goods for two main reasons: look for self-pleasure and become a symbol of success. When it matters of luxury goods, social media plays an important role (Godey et al, 2016). Previous research showed communication through sosia media is a promising strategy for luxury goods products (Schwedt et al, 2012; Godey et al, 2016). Over the past 10 years, social media has offered new opportunities for well-known brands and allowed them to create relationships with target markets (Gilliland, 2018). Data shows that fashion products are the most traded and traded products through social media, in addition to electronic products, gadgets, food, beauty products and household appliances. Fashion products include clothing, watches, bags, shoes, glasses and various other accessories that can support the appearance. A wide range of fashion brands are offered various social media platforms with various payment methods to obtain products. It is thought that it will be very difficult to obtain a high level of consumer loyalty towards a brand. Chu et al (2019) thought that branded products or services that consumers see are high quality products, offer authentic value through desirable benefits, either functional or emotional, have a prestigious 
image in a market built on quality, deserve to command premium prices and are able to inspire deep relationships with consumers.

\section{LITERATURE REVIEW}

\section{Social Media Marketing and Brand Equity}

Social networking sites have become increasingly important and are now forming a key area of academic research (Assimakopoulo et al, 2017). The explosion of user growth and the emergence of new platforms, along with the increased ability to access the internet offered by mobile devices, are affecting the behavior and lives of people from almost all socio-demographic groups around the world. Someone uses social media for entertainment, social networks and professional networks (Bheig and Khan, 2018). Social media is an excellent medium for providing customers with personal communication. E-retailers can create pages on social media and can place posts containing videos, messages, quizzes, information, and other materials. Customers can become fans on social media platforms, and then show that they are interested in the look and comment on it. This reflects the company's popularity and success on social media (Oberoia et al, 2017). The relationship between corporate social media activities and brand equity-based consumers is a field for media and managers trying to allocate resources to initiate the marketing process (Shay and Horst, 2019). According to Yadav and Rahhman (2018), there are five dimensions of social media marketing. It consist of interactivity, informativeness, personalization, trendiness and word of mouth.

The concept of brand equity (also known as customer-based brand equity) comes from the word consumer brand, but some experts argue brand equity also has relevance to industry customers (Baumgarth \& Schmidt, 2010). The process of purchasing industrial customers is primarily based on rational determinants such as product quality, specifications, delivery, product performance, service, and price (Aness and Johnston, 2018). Industry customers tend to rely on the reputation and brand image of suppliers to be more confident in their purchasing decisions (Brown et al 2011). Furthermore, there was a strong positive effect of Social media marketing on brand equity. Brands will have positive brand equity based on customers when consumers give a better reaction to posts on social media when brands are identified (Shay and Horst, 2019). This can translate into greater future predictions because customers can receive premium prices, price increases and brand presence when faced with competitors. Therefore, this study hypothesizes that in the role of intensive social media marketing there is a brand will increase confidence in a brand.

\section{Brand Equity and Consumer Loyalty}

Brand can be a characteristic that distinguishes a product from other similar products to remember so as to facilitate the consumer of a product ( Saputra et al, 2019). Brand equity is a means to gain a competitive edge that has become an important concept for marketers and academic researchers. Create successful results in the success of an organization, and resilience to competitors. According to Godey (2016), brand awareness and brand imagage are the dimension of brand equity. Through implementing branding strategies, marketers have for many years successfully branded their products and services (Shafaei, 2019). Brand equity is defined as subjective, subjective customer and intangible brand valuations well above and beyond the perceived objective value. Each brand has three strategic tasks. First, it facilitates in acquiring potential customers. Second, it reminds existing customers of the deals the company is given. Brand equity also assists customers in developing unique images of specific products and releasing from competitors (Keller et al., 2015; Yadav and Rahman, 2018). According to Mowen and Minor (2002, loyalty to the brand is the extent to which a customer shows a positive attitude towards a brand, has a commitment to a particular brand 
and intends to continue to repurchase in the future. Retaining all existing customers will be more profitable than attracting new customers when viewed in terms of costs (Octavia and Sriayudha, 2020).

Brand loyalty is inextricably linked to how the experience of using a product is. However, brand loyalty can't happen without first making a purchase and without having the experience of using it. The reflection of a consumer's attitude towards a brand depends on the experience that consumers feel during the use of the brand. Brand equity strategies can be used to gain customer loyalty (Yadav and Rahman, 2018). So, the first hypothesis is :

H1 : Social Media Marketing has a positive and significant relationship to consumer loyalty mediated by brand equity

\section{Social Media Marketing and Consumer Response}

Social media has led new online marketing practices and brought new ways for luxury brands to interact with consumers (Chu, et al, 2019). Kaplan and Haenlin (2010) state that social media is a group of internet-based applications using Web 2.0 ideology and technology, where users can create or exchange information using the app. Some social media that is very popular and has millions of users are Facebook, Twitter, Instagram, Youtube, Blog, and others. There are several factors that make social media users to give online word of mouth, including interpersonal connectivity, social influence, product involvement, and attitude towards online word of mouth. One of the advantages of social media is that it can show ads according to the tastes of the users. For marketers this can be profitable because it can facilitate in segmenting target customers (Moriansyah, 2015).

With the advancement of social media digital technology, each platform has its own characteristics and applies them to the context of luxury brand marketing. Especially, when it comes to luxury product marketing, Instagram is very visual and it making Instagram become the most popular luxury product social platform in terms of engagement, measured it by likes, dislikes, comments, sharing features and reactions (PMX Agency, 2017). Instagram users show higher brand community engagement than other users of social media platforms (Phua et al., 2017: Chu et al, 2019). Instagram has a visual image-based SNS, it is useful for researching consumer responses to social media marketing on Instragram, and comparing how consumers react differently to different types of social media in the context of luxury products. In addition, Boateng and Okoe (2015) investigated that consumer attitudes towards social media advertising and their behavioral responses. In that study, product and company reputation played an important role in the relationship between consumers' attitudes toward social media and their behavioral responses.

\section{Consumer Response and Consumer Loyalty}

According to Khare (2014), a cognitive response is a reaction based on the product information felt when using the product. It has dimensions that form the trust or categorization associated with the product. The establishment of beliefs about the product is the result of product durability, technical enhancement or visual factors. Along with the formation of trust, consumers will go through the process of categorizing in knowledge into certain categories. For cognitive responses, individual characteristics of consumers, such as engagement, motivation and understanding, have a relevant influence. In previous research on consumer responses and attitudes, product forms derived cognitive responses and affective responses are psychological: these responses form behavioral responses ( $\mathrm{Chu}$ et al, 2013; Kim et al, 2014). Thus, the consumer response can be interpreted as the main evaluation process before the establishment of attitudes towards the product.

Gaining consumer loyalty is the main marketing goal and building customer loyalty is a challenge. The theory states that the loyalty of the slow is the buying behavior that benefits 
the seller over its competitors (Watson, et al, 2015). Yadav and Rahman (2018) suggest that Outlook's behavior (which is visible from the outside) consists of positive actions indicated by customers in certain situations by purchasing products and delivering positive word of mouth (WOM), while avoiding the activity of expressing conflicting responses, for example, negative wom delivery, and no intention to buy. Loyalty can be defined as a highly held commitment to repurchasing or re-patroning consistently selected products and services in the future. A positive response from consumers will be to make a repurchasing, pass on information about the brand to others and recommend the brand. Based on that, we predict the second and the third hypothesis :

Hypothesis 2 : Social Media Marketing has a positive and significant relationship to consumer loyalty mediated by the consumer response

Hypothesis 3 : Social media marketing has a positive and significant relationship to consumer loyalty directly.

\section{RESEARCH METHOD}

The design of the research is a survey research design. This quantitative data used to analyze the model of research. It gained through data from structured quistionaire. The research instrument uses questionnaires sent online to respondents. To interpret quantitative results is also used literature studies. The population in this study is consumers of fashion products with well-known brands, including clothing, shoes, watches and other accessories. The data on the number of consumers of fashion products is not published and recorded but it is estimated that well-known brands that offer their products through social media are very large, so the determination of the number of samples is done by using Malhotra's opinion that for the use of SEM then a sample of at least 200 respondents. The sample determination technique uses a non probability sampling technique. The consumer criteria sampled are consumers of fashion branded products, male or female, have social media accounts, have made online purchases and are willing to be respondents.

\section{FINDING AND RESULTS}

Data is descriptively analyzed using SmartPls 2.0. The following table describes the characteristics of research respondents based on the age group, gender, occupation and type of social media used to shop for branded fashion products.

Table 1. Respondents Characteristic

\begin{tabular}{ccc}
\hline & Characteristic & Percent \\
\hline Age & $17-26$ years old & 48 \\
& $27-36$ years old & 23 \\
& $37-46$ years old & 25,5 \\
& $47-56$ years old & 3,5 \\
& $>56$ years old & 0 \\
\hline Gender & Men & 33,5 \\
& Women & 66,5 \\
\hline Occupation & Students & 34 \\
& Civil servant & 20,5 \\
& Honorary Officer & 12 \\
& Private Employee/ & 19,5 \\
& BUMN/BUMD & 7 \\
& Entrepreneur & 7 \\
\hline Social Media & House wife & 1 \\
& Youtube & 30
\end{tabular}




$\begin{array}{cc}\text { Instagram } & 56 \\ \text { Facebook } & 12,5 \\ \text { Twiter } & 0,5 \\ \text { Line } & 0\end{array}$

Sorcer : Data processed 2020.

The study respondents were predominantly female and the overall respondents were in the age range of 17-26 years. According to data from Kompas (2018), social media users are segmented based on age and needs. There was a nearly 50 percent increase in internet and social media users from the previous year. In purchasing, women tend to be influenced by the stronger quality of service whereas men are more influenced by the economic value of the product. Some research suggests that men make more online purchases. But other studies show different findings where women actually have planned purchases than men (Mulyono, 2012). 34 percent of respondents were students and 56 percent used Instagram as their active social media to shop for branded fashion products. Many users use Instagram to promote products. Posting photos, giving likes, commenting, following public figures and hashtags make Instagram a favorite to promote fashion branded products.

The relationship between social media marketing and consumer loyalty research is mediated by brand equity and consumer response. Mediation effect testing is done with Sobel $\mathrm{T}$ test. The decision to accept and reject the hypothesis is to compare between t-statistics and t-tables. Determination of the t-table value in this mediation test by determining degree of freedom $(\mathrm{DF})=\mathrm{n}-\mathrm{k} . \mathrm{n}$ is the number of samples and $\mathrm{k}$ is the number of research variables. Then DF for mediation effect testing with $n=200$ and $k=4$ is: $D F=200-4=196$. After being viewed in table $t$ with alpha 0.05 (two tail prob) then the table $t$ value is 1.97 . The mediation effect analysis step is to first calculate with smartpls 2.0 analysis tool for each variable as follows:

Table 2. The Influence of Brand Equity Mediation

\begin{tabular}{cccccc}
\hline & $\begin{array}{c}\text { Original } \\
\text { Sample } \\
(\mathbf{O})\end{array}$ & $\begin{array}{c}\text { Sample } \\
\text { Mean } \\
(\mathbf{M})\end{array}$ & $\begin{array}{c}\text { Standard } \\
\text { Deviation } \\
\text { (STDEV) }\end{array}$ & $\begin{array}{c}\text { Standard } \\
\text { Error } \\
\text { (STERR) }\end{array}$ & $\begin{array}{c}\text { T Statistics } \\
(\mid \mathbf{O} \text { (STERR|) }\end{array}$ \\
\hline $\begin{array}{c}\text { Brand Equity-> } \\
\text { Consumer Loyalty }\end{array}$ & 0.228742 & 0.229063 & 0.047792 & 0.047792 & 4.786178 \\
\hline $\begin{array}{c}\text { Social Media } \\
\text { Marketing -> Brand } \\
\text { Equity }\end{array}$ & 0.575878 & 0.57785 & 0.032507 & 0.032507 & 17.71555 \\
\hline $\begin{array}{c}\text { Social Media } \\
\text { Marketing -> } \\
\text { Consumen Loyalty }\end{array}$ & 0.558594 & 0.557805 & 0.042019 & 0.042019 & 13.29372 \\
\hline SOurces: Data Processed & & & & & \\
\hline
\end{tabular}

Sources : Data Processed 2020.

The results of the study in table 2 showed the influence between social media marketing and consumer loyalty both with brand equity mediation and without mediation. The effect of brand equity on consumer loyalty showed a statistical $\mathrm{T}$ value of $4.78>1.97$. Significantly brand equity affects the consumer loyalty of branded fashion products. Brand equity as a means of achieving competitive advantage has become a concept used by organizations. Successfully creating the equity of a fashion branded brand will lock in consumer confidence. Fashion products such as Channel, Gucci and Louis Vuitton are very 
easy for consumers to recognize by brand, logo and color. The success of manufacturers marketing fashion brands will have an impact on customer loyalty. Shafaei et al (2019) argues that through the implementation of branding strategies, marketing successfully embeds their products and services in the consumer's mind. Furthermore, the statistical T value of 17.71>1.97 showed a positive and significant influence between social media marketing and brand equity. These findings are in line with Shay and Horst's research (2019). They reported that a brand will have positive customer-based brand equity when consumers give a better reaction to posts on social media when a brand is identified. The results of this study are also in line with research conducted by Ananda et al (2017), in which they expressed a relationship with generic business strategy and marketing, MSMEs engaged in the world of Fashion has a common goal of raising brand awareness. The positive and significant influence between social media marketing and consumer loyalty was shown from a value of $13.29>1.97$. Yap and Lee (2014) researched that customer loyalty to social media networks can be attributed to the social influence, compatibility, pleasure and user behavior associated with what the company has to offer.

Next, from table 2 data obtained the beta value of the independent variable against the mediation variable is 0.5758 and the beta value of the dependent variable is 0.558 . Then the level of significance was above 1.97. This state proved that there is a positive and significant influence between social media marketing variables and consumer loyalty both before mediating and after mediating. Furthermore, sobel test is conducted online using danielsoper online calculator. From the calculation of sobel test obtained t-statistic value of 10.64 , because the $t$ statistic value obtained at $10.64>1.97$ with a significance level of $0.00<0.10$ then proves that brand equity is able to mediate the influence of social media marketing on consumer loyalty. So that the hypothesis is accepted.

Table 3. The Effect of Consumer Response Mediation

\begin{tabular}{cccccc}
\hline & $\begin{array}{c}\text { Original } \\
\text { Sample } \\
(\mathbf{O})\end{array}$ & $\begin{array}{c}\text { Sample } \\
\text { Mean } \\
(\mathbf{M})\end{array}$ & $\begin{array}{c}\text { Standard } \\
\text { Deviation } \\
(\text { STDEV) }\end{array}$ & $\begin{array}{c}\text { Standard } \\
\text { Error } \\
(\text { STERR) }\end{array}$ & $\begin{array}{c}\text { T Statistics } \\
(\mid \mathbf{O} \text { (STERR) }\end{array}$ \\
\hline $\begin{array}{c}\text { Consumer } \\
\text { Response -> } \\
\text { Consumer Loyalty }\end{array}$ & 0.11147 & 0.114829 & 0.038329 & 0.038329 & 2.908242 \\
\hline $\begin{array}{c}\text { Social Media } \\
\text { Marketing-> } \\
\text { Consumer Loyalty }\end{array}$ & 0.641627 & 0.640949 & 0.032262 & 0.032262 & 19.88801 \\
\hline $\begin{array}{c}\text { Social Media } \\
\text { Marketing -> } \\
\text { Consumer } \\
\text { Response }\end{array}$ & 0.414911 & 0.41883 & 0.037188 & 0.037188 & 11.15721 \\
\hline
\end{tabular}

Source:Data Processed 2020.

The effect of consumer response to consumer loyalty in table 3 showed positive and significant results with a value of 2.90 . The consumer's response to the product will be to respond after a series of communication both psychologically and sensationally after using the product. Furthermore, there is a positive and significant influence between social media marketing and consumer loyalty with a statistical T value of 19.88. Valos et al (2016) found that consumer perception of luxury brands was significantly linked to satisfaction and intent 
to use social media platforms. Social media marketing has an influence on the consumer response of branded fashion products with a t statitik value of 11.15. In line with research conducted by Godey et al (2016) which states each social media marketing strategy should pay special attention to an content that is entertaining, current, and tends to stimulate consumer engagement and interaction.

From the calculation of sobel test obtained t-statistic value of 9.73 , because the $t$ statistic value obtained by $9.73>1.97$ with a significance level of $0.00<0.10$ then proves that the consumer response is able to mediate the influence of social media marketing on consumer loyalty so that the hypothesis can be proven. In the luxury products sector, social media seems to play a key role in marketing success because it gets a good response from consumers. Some cases show the model's connection. For example, Louis Vuitton (LV) posted a video of the catwalk presentation on its Facebook page, giving all LV fans the opportunity to enjoy the show (Kapferer, 2012). Burberry launched an online shopping site for consumers in China and offers 24-hour customer service through an online chat system (Godey et al, 2016). This received a good reception from Burberry consumers in China. Valos et al (2016) found that consumer perception of luxury brands was significantly linked to satisfaction and intent to use social media platforms.

\section{CONCLUSION}

Social media marketing is significantly influence the consumer loyalty of branded fashion products either directly or indirectly by being mediated by brand equity. Social media marketing is also significantly influence to consumer loyalty of branded fashion products both directly and indirectly by being mediated by consumer response. More research still needs to be done to examine the extent to which the role of these variables is primarily related to business performance. The implication of research lies in how digital development in marketing contributes thought to the business world and government policy. Further rsearch is still need to be strengthens in order to develop theory for similar research.

\section{REFERENCES}

Abdulrazak, R.M \& Gbadamosi, A (2017). Trust, religiosity and relationship marketing : a conceptual overview of consumer brand loyalty. Society and Business Review Vol.12 No.3, 2017 pp. 320-339.

Ananda, A.S., Garcia, A.H \& Lamberti, L (2017). SME fashion brands and social media marketing: from strategies to actions. Int. J. Web Based Communities, Vol. 13, No. 4, 2017. Inderscience Enterprises Ltd.

Aness., M.R., \& Johnston., W.J. (2018). How multiple strategic orientations impact brand equity of B2B SMEs. Journal of Strategic Marketing, Volume 27, 2019 - Issue 8.

Assimakopoulos, C., Antoniadis, I., Kayas, O.G. \& Dvizac, D. (2017) "Effective social media marketing strategy: Facebook as an opportunity for universities", International Journal of Retail \& Distribution Management, Vol. 45 Issue: 5, pp.532-549.

Baumgarth, C. (2010). "Living the brand": Brand orientation in the business-to-business sector. European Journal of Marketing, 44, 653-671.

Beig, F.A \& Khan, M,F (2018). Impact of Social Media Marketing on Brand Experience: A Study of Select Apparel Brands on Facebook. SAGE Publications. 22(3) 1-12.

Boateng, H., \& Okoe, A. F. (2015). Consumers' attitude towards social media advertising and their behavioural response: The moderating role of corporate reputation. Journal of Research in Interactive Marketing, 9(4), 299-312.

Brown, B. P., Zablah, A. R., Bellenger, D. N., \& Johnston, W. J. (2011). When do B2B brands influence the decision making of organizational buyers? An examination of the 
relationship between purchase risk and brand sensitivity. International Journal of Research in Marketing, 28, 194-204.

Chu, S.C., Kamal, S. \& Kim, Y (2019) Re-examining of consumers' responses toward social media advertising and purchase intention toward luxury products from 2013 to 2018: A retrospective commentary, Journal of Global Fashion Marketing, 10:1, 81-92.

Gen Li., Juan Li \& Sun, X (2020). Measuring Green Brand Equity In Relationship Interaction and Its Impact On Brand Loyalty. Revista de cercetare și intervenție socială, 2019, vol. 66, pp. 278-297.

Gilliland, N. (2018). Why Chanel is the most influential luxury brand on social. Econsultancy. Retrieved from https://www.econsultancy.com/blog/69942-why-chanel-isthe-most-influential -luxury-brand-on-social

Goody, B., Manthiou, A., Pederzou, D., Rokka, J., Aleilo, G Donviro, R \& Singh, R. (2016). Social Media Marketing Effort of Luxury Brand : Influence On Brand Equity and Consumer Behaviour. Journal of Business Research. 0146-2963.

Han, J., Jun, M \& Kim, M. (2019). Impact of online community engagement on community loyalty and social well-being. Social Behavior and Personality, Volume 47, Issue 1, e7545

Kapferer, J. N. (2012). New strategic Brand Management: Advanced insights and strategic thinking (5th ed.). London, GBR: Kogan Page Ltd, 2012.

Kaplan, A,M., \& Haenlein, M. (2010). Users of the world, unite! The challenges and opportunities of social media. Business Horizons, Vol. 53 No. 1, pp. 59-68.

Keller, K.L., Parameswaran, A.M. and Jacob, I. (2015), Strategic Brand Management: Building, Measuring, and Managing Brand Equity, Pearson, Noida.

Khare, A. (2014). Antecedents to fashion clothing involvement: Role of global self-identity, cosmopolitanism, and normative influence. Journal of Global Fashion Marketing, 5, 39 59.

Kim, K., Ko, E., Lee, Mi-ah., Mattila, P. \& Kim, K.H. (2014). Fashion collaboration effects on consumer response and customer equity in global luxury and SPA brand marketing. Journal of Global Scholars of Marketing Science, 2014 Vol. 24, No. 3, 350-364.

Kompas. (2017, 28 Maret). Perjalanan Uniqlo untuk jadi perusahaan berskala dunia. Kompas.com. Retrieved from: https://biz.kompas.com/read/2017/03/28/17070 2828/perjalanan.uniqlo.untuk.jadi.perusahaan.berskala.dunia.

Lee, S.H \& Jung, K.S (2019). Loyal Customer Behaviors : Identifying Brand Fans. Social Behavior and Personality, 2018, 46(8), 1285-1304.

Lee, S.M., Kim, S.Y \& Kim, D.Y. (2019). Effect of program type and reward timing on customer loyalty: The role of the sunk cost effect. Social Behavior and Personality: An international journal, 47(11), e8407

Moriansyah, L. (2015). Pemasaran Melalui Media Sosial: Antecedents Dan Consequences Social Media Marketing: Antecedents And Consequences. Jurnal Penelitian Komunikasi dan Opini Publik Vol. 19 No.3.

Mowen, C. John, \& Michael Minor. 2002. Perilaku Konsumen. Dialihbahasakan Oleh Dwi Kartini Yahya. Jilid 2. Ed. 5. Jakarta: Erlangga.

Mulyono, Fransisca. 2012. Faktor Demografis Dalam Perilaku Pembelian Impulsif. Jurnal Administrasi bisnis, 8(1), h: 88-105

Oberoia, P., Patelb, C \& Haonb, C. (2017). Technology sourcing for website personalization and social media marketing: A study of e-retailing industry. Journal of Business Research 80 (2017) 10-23.

Octavia, A., Indrawijaya, S., Sriayudha, Y, Heriberta, Hasbulla, H \& Asrini (2020). Impact On E-Commerce Adoption On Entrepreneurial Orientation In Business Performance of SMEs. Asian Economic and Financial Review. Vol. 10, No. 5, 516-525. 
Octavia, A., \& Sriayudha, Y. (2020). Selfie Marketing abd Customer Loyalty : Mediating Role Of Experiential Shopping. Jurnal Ilmu Manajemen Terapan, 1(3), 231-238. https://doi.org/10.31933/jimt.v1i3.100.

Phua, J., Jin, S. V., \& Kim, J. (2017). Uses and gratifications of social networking sites for bridging and bonding social capital: A comparison of Facebook, Twitter, Instagram, and Snapchat. Computers in Human Behavior, 72, 115-122.

PMX Agency. 2017. Instagram is the top social media site for luxury retail shoppers. Retrieved from https://www.pmxagency.com/blog/2017/09/instagram-top-social-mediasite-luxuryretail-shoppers/.

Saputra, M.A., Octavia, A., Roza, S \& Sriayudha, Y (2019). Negara Asal Produk, Persepsi Kualitas dan Merek: Pengaruhnya terhadap Keputusan Pembelian Smartphone. Jurnal Samudra Ekonomi dan Bisnis. Vol 10, No.1.

Schwedt, G., Chevalier, M \& Gutsatz, M. (2012). Luxury Retail Management : How the World's Top Brands Provide Quality Product and Service support. Hoboken, NJ. USA, Wiley.

Shafaei, A., Nejati, M., \& Maadad, N. (2019): Brand equity of academics: demystifying the process. Journal of Marketing for Higher Education, DOI: 10.108008841241.2019.1605438.

Shay, R \& Horst, M.V.D (2019): Using Brand Equity to Model ROI for Social Media Marketing, International Journal on Media Management, DOI: 10.1080/14241277.2019.1590838.

Valos, M.J., Habibi, F.H., Casidy, R, Driesener, C.B \& Maplestone, V. L (2016). Exploring the integration of social media within integrated marketing communication frameworks. Marketing Intelligence \& Planning, Vol. 34 Iss 1 pp. $19-40$.

Watson, G.F., Beck, J.T., Henderson, C.M \& Palmatier, R.W (2015). Building, measuring, and profiting from customer loyalty. J. of the Acad. Mark. Sci. DOI 10.1007/s11747-0150439-4

Yadav, M \& Rahman, R. (2018) "The influence of social media marketing activities on customer loyalty: A study of e-commerce industry". Benchmarking: An International Journal, Vol. 25 Issue: 9.

Yang, S.J \& Lee, Y (2019). Mid- to low-end fashion brand personality affects consumers' perceived quality, commitment, and loyalty. Social Behavior and Personality: An international journal, 47(7), e7680.

Yap, S.F.C. \& Lee, C.K.C. (2014), "Leveraging the power of online social networks: a contingency approach", Marketing Intelligence \& Planning, Vol. 32 No. 3, pp. 345-374. 